Article

\title{
Leak Early, Leak (More Than) Often: Outlining the Affective Politics of Data Leaks in Network Ecologies
}

\author{
Alberto Micali ${ }^{1,2}$ \\ ${ }^{1}$ Communications Faculty, John Cabot University, Rome, 00165, Italy; E-Mail: amicali@johncabot.edu \\ ${ }^{2}$ School of Film and Media, University of Lincoln, LN67TS Lincoln, UK; E-Mail: amicali@lincoln.ac.uk
}

Submitted: 27 February 2018 | Accepted: 10 May 2018 | Published: 11 September 2018

\begin{abstract}
Data leaks have become one of the most ubiquitous weapons in the arsenal of digital media dissent. However, often such processes of mediation exceed a rational understanding of the information revealed. Acting in the domain of the accident, the mediations of leaks operate in the dimension of the event: an immanent and particular set of relations that is provoked by the encounter and collision of various forces, virtually becoming their productive potential. This article advances the question of how data leaks - as a form of media dissent-operate beyond representation, touching upon the vital realm of affect. Intensively enabling a transformation in the state of the forces at play, affect generates possibilities within the emergent world that is constantly in creation. In this article, I argue that the politics of leaks in contemporary network ecologies works in such an affective register, possessing the capabilities to trigger and activate subjects differentially. Exploring the 2012 leak by Anonymous Italia, consisting of around 3,500 Italian police documents, mostly concerning the NoTav movement, I propose that the mediations of data leaks need to be studied and apprehended via their inductive capacities, as a question of affective politics, or alter-politics.
\end{abstract}

\section{Keywords}

affect; affective politics; affect theory; Anonymous; data leaks; media theory; nonrepresentational theory; NoTav movement

\section{Issue}

This article is part of the issue "The Turn to Affect and Emotion in Media Studies", edited by Margreth Lünenborg and Tanja Maier (Free University Berlin, Germany).

(C) 2018 by the author; licensee Cogitatio (Lisbon, Portugal). This article is licensed under a Creative Commons Attribution 4.0 International License (CC BY).

And there is a youth sleeping in a little park. Tío Pepe drops a coin by the boy's head. Bending down to pick up the coin he whispers... "un joven muerto" ("a dead youth"). -William S. Burroughs, 1971, 10

\section{Introduction}

With the mass commercialisation of the internet, the parallel development of the databasing capacities of digital archives, and the consequential increasing value of stored information, data leaks have come dramatically to the fore of contemporary societies. In recent decades, media organisations such as "WikiLeaks", loose hacktivists networks such as "Anonymous", as well as individual whistle-blowers such as Edward Snowden, have garnered global attention thanks to the public release of massive amounts of classified information. Data leaks have thus risen to prominence and have become a widespread "weapon" of political dissent. ${ }^{1}$

In particular, the politically motivated use of data leaking characterises the politics of media dissent employed by Anonymous. Since the launch of Operation AntiSec (Anti-Security) in 2011, various groups working behind the facemask of Anonymous have exploited digital networks and databases in order to bring to public at-

\footnotetext{
${ }^{1}$ The use of the word weapon here is not metaphorical. A media object can become a weapon according to the process in which it is caught or, in the words of Deleuze and Guattari (1987), to the machine it will concatenate with-in this case a war machine. For details, see Micali (2016).
} 
tention an increasing volume of data and emergent vulnerabilities. ${ }^{2}$ This article has a programmatic objective; its aim is to outline the politics of data leaks by advancing a proposal that pivots around developments in affect theory. Rather than offering answers or a comprehensive account of the topic, I instead draft a new possibility to comprehend the "logic" - the way of functioning - of this increasingly widespread form of digital interventionism. The programmatic scope of the article also reflects the style of presentation of the argument, which-instead of applying a definite framework of analysis to a specific case-will offer the latter as a starting point from which to extract, map, and delineate a possible new direction for the understanding of the phenomenon in question. ${ }^{3}$

To begin with, I introduce a specific focus that moves the lens of analysis of the politics of media dissent, and in particular of Anonymous, from an Anglo-American to an Italian context. Emphasis will be given to a data leak that in 2012 exposed the "pre-emptive" strategies (Elmer \& Opel, 2006, 2008) that have been applied by Italian police against the NoTav grassroots movement. From an overview of this case, $I$ argue that positing data leaks within a representational-oriented framework largely misses many of the crucial issues at stake in the politics of this contemporary "style" of digital resistance, overlooking the capacities of their mediations. ${ }^{4}$ Subsequently, and for this reason, I am going to address the question of virtuality within leaks. Indeed, this virtual element-especially in relation to issues of information overload-emerges as a central problem, one that permits the argument to move towards the consideration of an intensive order: a domain that is centrally implicated within leaking processes of mediation.

Bringing forward this relevance for intensity means that-in the final part of the article-I take a specific position on contemporary debates concerning affect, sustaining the line of thought that from Baruch Spinoza (1667/2013) passes through the writings of Gilles Deleuze and Félix Guattari (Deleuze, 1992, 2001,
2013; Deleuze \& Guattari, 1987; Guattari, 1990, 1995) to the recent proposals of Brian Massumi (2002, 2010, 2015a, 2015b)-specifically his idea of affective politics. The article concludes with some preliminary remarks on the key relationships that connect the AntiSec data leak activated by Anonymous to the NoTav movement, opening as such, the floor for future developments in the understanding of the affective dimensions at stake in digital data leaking.

\section{2011, 2012 Anonymous Operation Antisec: "Is There Any Problem, Officer?"}

In the summer of 2011, Anonymous was experiencing a dandelion-like event: the spread of contagious, constitutive diagrams; a network of new relations, of original becoming-Anonymous was forming worldwide. ${ }^{5}$ According to Coleman (2014), "where previously a single IRC network (AnonOps) and a breakaway group (LulzSec) dominated the North American and European Scene, an archipelago of hacker islands...emerged from the Anonymous water" (p. 283). Up to this point, the network of AnonOps had led several mass deployments of Anonymous weaponry, whilst LulzSec-a small cell that temporarily surfaced within Anonymous, focusing on exploiting computer systems by leaking and "doxing" large amounts of data-were "the world's leaders in highquality entertainment at your expense" (as cited in Olson, 2012, p. 248).

On the one hand, leaking had achieved international recognition thanks to WikiLeaks and its publication of considerable amounts of secreted information since 2006. On the other hand, "doxing" is the practice of looking for (mostly by exploiting systems with code) and publishing personal data on the internet. This latter form of digital interventionism may be undertaken for various reasons. However, anti-security movements generally aim to make the public aware of issues of vulnerability, which may exist in private or public computing services. ${ }^{6}$

\footnotetext{
${ }^{2}$ Operation AntiSec finds its roots in a larger movement that flourished in the period of the mass distribution of the internet among hackers. In particular, so-called "black hat" hackers started to look for and publicise data, opposing the public disclosure of systems' vulnerabilities (especially zero-day exploits; see for instance Jordan, 2008; Thomas, 2002, pp. 42-46). The AntiSec renaissance under the Anonymous facemask also links to the full commercialisation of the internet that have occurred since the turn of the millennium.

${ }^{3}$ The argument does not follow a traditional structural line, attempting to overcome the rigid separation between the subject and object(s) of study, that is by positing a possible theory of the politics of data leaks and the related practices on the same ontological and epistemological level-what Félix Guattari $(1995,2006)$ defined the "plane of consistency". Two references that make and endeavour to stylistically de-hierarchise the separation in question are here cardinal: first, William S. Burroughs's writings, and in particular the novels of the so-called "Nova Trilogy" (Burroughs, 1961; 1962; 1964); and, second, Gilles Deleuze and Félix Guattari's A Thousand Plateaux (1987). In both cases, the question of style becomes preeminent, being addressed by a particular mode of exposition.

${ }^{4}$ Implicitly, I am assuming here a vitalist and post-anthropocentric perspective on media and mediation. This means that my analysis does not start from a consideration of media as pre-existing, static objects, nor do I presuppose them as mere prostheses useful to represent the political issues of the day. As such, my position distances itself from the emerging framework of data activism that-coming from social movement studies-always presupposes media as prosthetic tools to represent human culture, and thus remains enmeshed in anthropocentrism and representationalism. For details on a vitalist perspective on mediation within a post-Cartesian framework, see for example the work of Sarah Kember and Joanna Zylinska (2012).

${ }^{5}$ Tatiana Bazzichelli (2013, p. 138) draws attention to the vital and material lines traversing the actualisation of the hacktivism of Anonymous. As such, she offers an anti-metaphorical discussion that aligns the contagious diagrams of Anonymous to dandelions.

${ }^{6}$ Anti security groups reflect the attitude towards knowledge and its application of mastery that is at the core of hacking. A body of literature on antisecurity movements does not exist, since the involved groups avoid the representation of institutionalised politics, sharing their issues through digital networks rather than making their issues and claims visible for a mass public. However, from the literature on hacker culture it is easy to sense the relevance of such issues, since these implicate the values of the hacker ethos-particularly, sharing without the limits of authority. Otherwise, the web is the repository from which information about anti-security can be sourced. A wider analysis of anti-security is beyond the scope of this article, and only a broad understanding of it seems necessary here.
} 
Amongst the several "islands" surfacing in Anonymous, the issue of security had begun to occupy an increasingly central position. Cells such as LulzSec converged their efforts on the practice of exploiting systems to cause the continual leaking of data. On the $19^{\text {th }}$ of June 2011, LulzSec posted a call to arms under the flag of "Operation AntiSec". 7 This operation, in contrast to previous LulzSec media actions, was launched as a project directly related to Anonymous (Anonymous, 2011).

The different media actions of political dissentor hacktions, as I described them elsewhere (Micali, 2017a)-deployed as part of the AntiSec campaign were numerous. ${ }^{8}$ Two days after the publication of the "call to arms", on the $23^{\text {rd }}$ of June, a series of private intelligence communications, training manuals, private emails, names, phone numbers, and passwords belonging to Arizona law enforcement officials were published under the title "Chinga La Migra" (Arizona Department of Public Safety, 2011; Constantin, 2011). ${ }^{9}$ This "data dumping" was part of a campaign to oppose the violent rejection of human migrants through the southern border of the US. In addition, other sheriffs' offices were "doxed," police websites defaced, and personal information-related to New York police chiefs-was leaked (Chapman, 2011). According to previous studies on Anonymous, in the month of July alone, the AntiSec Operation targeted 77 different law enforcement agencies, dumping a considerable amount of their data on the internet (Coleman, 2014; Olson, 2012). Nevertheless, alongside these hacktions, several other Anonymous-becomings were activated worldwide, following the distributed relays of digital media. While the Anglo-American context is widely discussed in literature concerned with Anonymous, the same cannot be said for media actions actualised through other nodes of the distributed hacktivist network. This is the case of Anonymous Italia, whose politics of media dissent hasinterestingly-concentrated on data leaks.

On the 22nd October 2012, Anonymous "owned and exposed" the Italian police according to one of the flyers that was distributed to publicise the hacktions (Figure 1). On the webpage of Anon-News (one of the leading blogs of Anonymous Italia), a post under the tag "Operation Police" claimed responsibility for the action; this was a leak media action undertaken as part of the AntiSec campaign (Anonymous, 2012). On the banner, a black and white picture shows an Anon wearing a Fawkes mask; this person is strangling a police officer from behind-a police officer who, for the occasion, is portrayed as a pig. Under this central image, the word "outnumbered" stands out, highlighting the idea that a difference in force can be actively defeated by a difference in numbers.

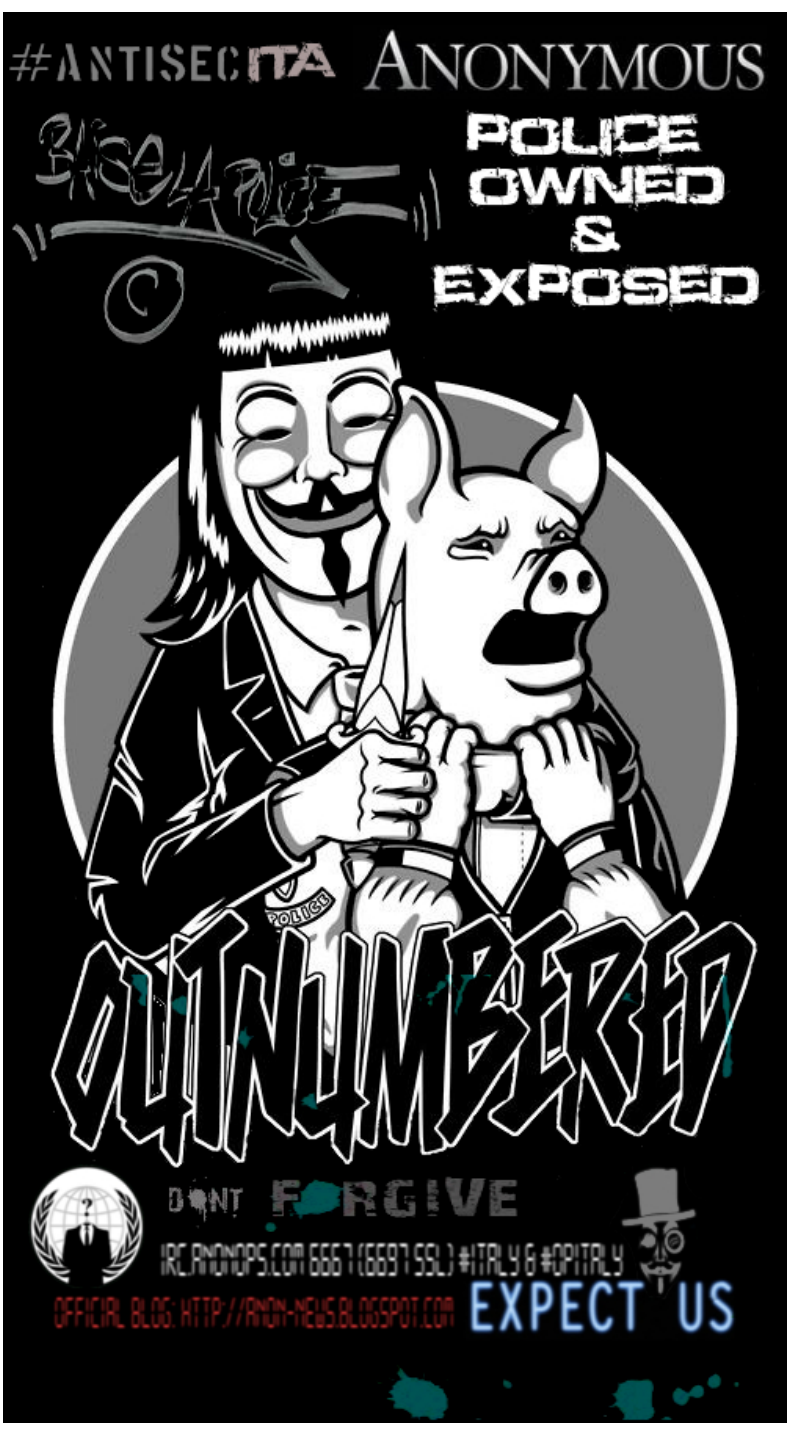

Figure 1. "Operation Police" part of Operation AntiSec. Flyer created and circulated by Anonymous to present the publication of a leak comprising documents of Italian police (Anonymous, 2012).

Together with these visual triggers, details regarding how to be involved and participate in Anonymous's operations make up the rest of the flyer. The blog post introduced the hacktion as follows:

For several weeks, we have enjoyed browsing your servers, emails, web portals, documents, reports and much more. We are in possession of a remarkable quantity of material: for instance, documents on systems of wiretapping, communication transcripts, new-

\footnotetext{
${ }^{7}$ One of the salient passages of the call reads as follows: "Top priority is to steal and leak any classified government information, including email spools and documentation. Prime targets are banks and other high-ranking establishments. If they try to censor our progress, we will obliterate the censor with cannonfire anointed with lizard blood. It's now or never. Come aboard, we're expecting you" (Anonymous, 2011).

${ }^{8}$ The term hacktion refers here to digital media action of resistance. I developed this concept in order to processually recharge this idea beyond a dualist perspective through a critical post-humanist framework that is capable of stressing the ontological heterogeneity of digital media and network interventionism. For details, see Micali (2017a).

9 "La Migra" is a slang term for U.S. Immigration and Customs Enforcement, or other immigration law enforcement agencies. From Spanish, the whole phrase can be translated as "Fuck the Immigration Police".
} 
generation microphones, undercover activities; files about NoTav and political dissidents; different circular letters, but also emails, some of which demonstrate your dishonesty (for instance, a communication where it is explained how to appropriate a weapon confiscated from a foreigner without facing the offence of handling stolen goods). Contrary to what we imagined, the level of security in your systems is really poor, and we are taking advantage of this to take our revenge...Is there any problem, officer? (Anonymous, 2012)

The hacktion consisted of obtaining and releasing around 3,500 classified documents of the Italian Polizia di Stato (state police)-one of the five national police forces in Italy. The release included more than a gigabyte of data, all of which were archived, ordered and published to be available online via the web platform "Paranoia", which was an international whistle-blowing website set up by Anonymous in the summer of 2012. Given that the operation ran under the flag of the AntiSec campaign, the issue of security might at first glance seem central. However, closer examination reveals that this is not the most urgent issue, which is instead related to the cultural specificities of the territories that co-constitute the action in question-in particular the specific local struggles that were, in the meantime, being fought in the north of the Italian peninsula. ${ }^{10}$

According to a public release made by Anonymous, data were gathered directly from the police servers, and their contents were diverse in nature. For instance, in one of the folders made available, it was possible to read a substantial amount of information collected by the Italian police about the NoTav movement. NoTav is a grassroots movement that has, since the end of the 1990s, opposed the construction of a high-speed rail link intended to "accelerate" the connection between the cities of Turin and Lyon. ${ }^{11}$ These documents consist of extracts from police investigations into the movement, internal memos of the Ministero degli Interni (the Home Office upon which, in Italy, the police are dependent), and the biographies and penal profiles of activists written by police officers. Among the data there is also a long document edited by the police headquarters in Turin, which outlines the supposed "structure" of the grassroots group by analysing the relationships that exist between the various activists. ${ }^{12}$ Moreover, the "dumping" also included intelligence manuals on how to conduct undercover operations to destabilise demonstrations through illegal actions; sets of forms for routine operations, such as police verifications and search warrants; database documents detailing the technical specificities for placing wire taps and electronic bugs; guidebooks for tracking mobile phone conversations; details on the relationships between Italian police and Interpol; and, finally, emails, telephone numbers, and names of public officials and police officers (II Fatto Quotidiano, 2012; InfoFreeFlow, 2012). The data dump consisted of information that is of public interest (i.e., how the police are allowed to act beyond the law) and the less relevant one (i.e., simple routine documents), as well as private information concerning police officers.

A public statement by Anonymous completed the leak (as cited in NoTav.info, 2012). This statement claimed responsibility for the hacktion, explaining the motivations behind its deployment. Here, the behaviour of the Italian police is stigmatised by introducing a series of brutal actions that occurred in the past: cases in which police officers were involved and condemned for their violence (particularly during past Italian political demonstrations, and within institutions such as prisons, psychiatric hospitals or immigration detention centres). ${ }^{13}$ The behaviour of the police is stigmatised as violent and oppressive, and labelled as "punishment and surveillance", reversing the title of Foucault's well-known work, Surveiller et Punir, (1975/1995). The statement also highlighted the relevance of the dumped data, introducing the content of various documents, such as the "colourful" description of NoTav activists provided by the police, as well as the widespread activity of monitoring Facebook profiles, through which the "likes" users placed to express their approval of certain associations were studied to prevent possible forms of dissent. ${ }^{14}$ Finally,

\footnotetext{
10 My use of the word "territory" aligns with Gilles Deleuze and Félix Guattari's conceptualisation. The theme of the territory provides a common thread that is woven through much of their work (see Guareschi, 2001; Parr, 2010). This concept is used in broader terms compared with its usage in ethology and ethnology, and can be thought of as the temporary bordering of a certain set of relations. It is not possible here to provide an in-depth analysis of the concept of the territory. For details, see Guattari (2006).

11 Details about the NoTav movement can be found online (http://www.notav.info), in Italian. The movement is a reference point for Italian antagonist political movements for many reasons. The NoTav movement first emerged at the end of the 1990s, when the high-speed rail track project was approved. This project has to cross the Occitan valley of "Val Susa" (North West of Italy) by building a new track rather than improving the existing one. The project met with hostility of the people living in the area, who have been actively fighting the project for around 20 years. During these years, the movement supported its actions via documents certifying all the problems regarding the building of the new train track, attracting significant support from other grassroots movements and many political forces. Its struggles are in fact related to the political proposition of the "commons", involving the possibility to autonomously decide about a natural territory in which people live. Without entering into detail, a publication by the Centro Sociale Askatasuna (2012) reorganises their 20 years of struggle through interviews with many of the activists involved. Another very valuable and accurate account of the struggles and main motives of the movement can be found in Wu Ming 1 (2016) while, for a ethnography of the movement, see Aime (2016).

12 Despite the police's assumptions, this is a "supposed structure" because non-hierarchical movements are not formed in any way by a "structure" (which is a hierarchical definition of the relationships at stake). Regarding the decision-making processes within the NoTav movement, see Centro Sociale Askatasuna (2012).

${ }^{13}$ In order to clarify these claims, particularly regarding detention, it seems relevant to specify that in the Italian context the issue of detention is a wellrecognised social problem that pertains to many institutions such as prisons, OPGs (Ospedali Psichiatrici Giudiziari [Juridical Psychiatrist Hospitals]), and CIEs (Centri di Identificazione ed Espulsione [Centres for Identification and Expulsion]).

14 In this case, a user who "liked" the Facebook page of an association fighting for animal rights was identified by the police as a potential, subversive threat.
} 
the release was a means by which Anonymous could advance legal propositions that may be able to limit the brutality of the police: the legal introduction of the offence of torture; the public availability of live camera footage to "counter-monitor" police during demonstrations; and the introduction of identification numbers on police officers' uniforms to allow their public recognition in the case of violent demonstrations. The Anonymous' declaration ends by poetically dedicating the hacktion to those who had suffered at the hands of the police's illegal behaviour:

This is for you, workers, who still have the strength to demonstrate in the streets, in spite of the fatigue of work. This is for you, students, who demonstrate for a better future and are brutally hit with truncheons. This is for you, the marginalised, the imprisoned, the maladjusted, who every day suffer the barbarism of these villains. This is for you, who are daily killed by the State, in jails and outside. This is for you, "bro, our brothers and sisters Anons, who are persecuted and arrested. This is for you, NoTav activists, who with courage for years have conducted your fights, blocked by these infamous and cowardly pseudo-men in uniform. This is for you, mothers, who despite your pain...are still looking for the truth and justice for your sons, savagely torn from you by those who ought to protect them. This is for you, foreign brothers, who escape from desperation to seek safety, and find the welcome of those who humiliate, torture and refuse you, masking racism behind the justification of public order. (as cited in NoTav.info, 2012)

Anonymous connotes the hacktion as existing within a "cyber-vigilant" framework. ${ }^{15}$ Indeed, the document ends with the slogan, in Latin, "we control the controllers" (see Figure 2). Here, the obvious significance of the cultural, social, and political milieu is the first aspect that is worth noting. However, this milieu does not merely frame the action, but rather is directly entangled in its actualisation: instead of defining it from the outside, the territory becomes part of the intervention, and the relation with the NoTav movement clearly foregrounds it as decisive. Second, and crucially for the argument, the specific media action at stake-a data leak-seems to act beyond the informative content it conveys, symptomatically signalling the surfacing of an innovative set of relationships between media and politics.
Leaks arise, thus, as innovative "databasing" media interventions; as processes of mediation in which the representational character of information looks like being less relevant, whilst the "quantity" emerges as the crucial element by which it is qualified. ${ }^{16}$ Consequently, it is to this point that I turn first, as it brings forward essential questions regarding the virtual character and intensive capacities of leaks. Subsequently, after expanding the argument by introducing the related and key domain of affective order, I proceed to briefly address-as a matter of programmatic conclusion-the significant entanglements that exist between Anonymous's data leak and NoTav.

\section{Beyond Representation: Virtuality and the Symptomatic Paradox of Digital Cultures}

The disproportionate dimension of dumped data acts by turning against the storage capabilities of databases. This means that leaks, as one of the key styles of contemporary digital media dissent, imply a molecular and material quality of affective order that goes beyond mere issues of the symbolic representation of a certain political cause.

The digital multiplication of media forms, and the perpetual immediacy of their production and consumption, can here be associated with the explosive scenario of the "information bomb". This scenario is the "great accident", the fuse of the electronic bomb, which Virilio (2000) describes by drawing from Einstein's suggestions. Such a bomb is an electronic overload that collides with the speeding up of immediacy, leading not to a temporary blockade (as, for instance, happens with digital swarms; see Micali, 2017b), but to the origination of a never-ending source that inserts itself at the top of a life cycle of perpetual data production. ${ }^{17}$ Within this bomb scenario, the augmentation of the "quantity" of information is proportional to the increasing capacity of archiving that has been reached through digital technologies. Furthermore, virtually, this quantitative "quality" does not rely only on this actual, improving storage capacity, but also on the continual and unstoppable elaboration of new data that have yet to be leaked. The affective turbulence of leaks implicates the ceaseless and circular process of producing and archiving data.

For this reason, the leak seems to have virtual capabilities that are able to viscerally affect the media hypertrophy of contemporary network ecologies, and par-

\footnotetext{
15 Cyber or internet vigilantism is a label used to describe actions through digital media and networks that are aimed to monitor and intervene against certain behaviours. Amongst journalists, Anonymous is often misread as a cyber-vigilante phenomenon, and examples can be found in Serracino-Inglott (2013). Such a perspective on the hacktivism of Anonymous is directly linked to the emergent discourse of transparency, which is analysed in terms of a radical ideology by Ippolita (2012).

16 This proposal on the nonrepresentationalist character of data leaks stands in opposition to recent proposals regarding data activism. As explained in footnote 4, by fostering a non-anthropocentric framework of analysis, I do not presuppose media objects as tools for the representation of political dissent, but rather as processes of mediation-as active agents that have the capability of shaping the becoming of contemporary digital media interventionism. For details, see Micali (2016).

17 Berardi (2004) also bases his argument on cybertime-and the psychopathologies suffered by human bodies in relation to it-on Virilio's suggestions regarding this acceleration towards immediacy. My point here is less centred on the consequences for the human of such an acceleration. Rather, I suggest that leaks need to be considered within such a scenario, but that this is not simply an information overload scenario (which is key in Berardi's argument). Such an overload involves the depletion of life in relation to the virtual and the continual origination and archiving of (big) data (which have material consequences for life-and not merely the human). As such, this is an implicit critique of what I like to call "big data epistemologies".
} 


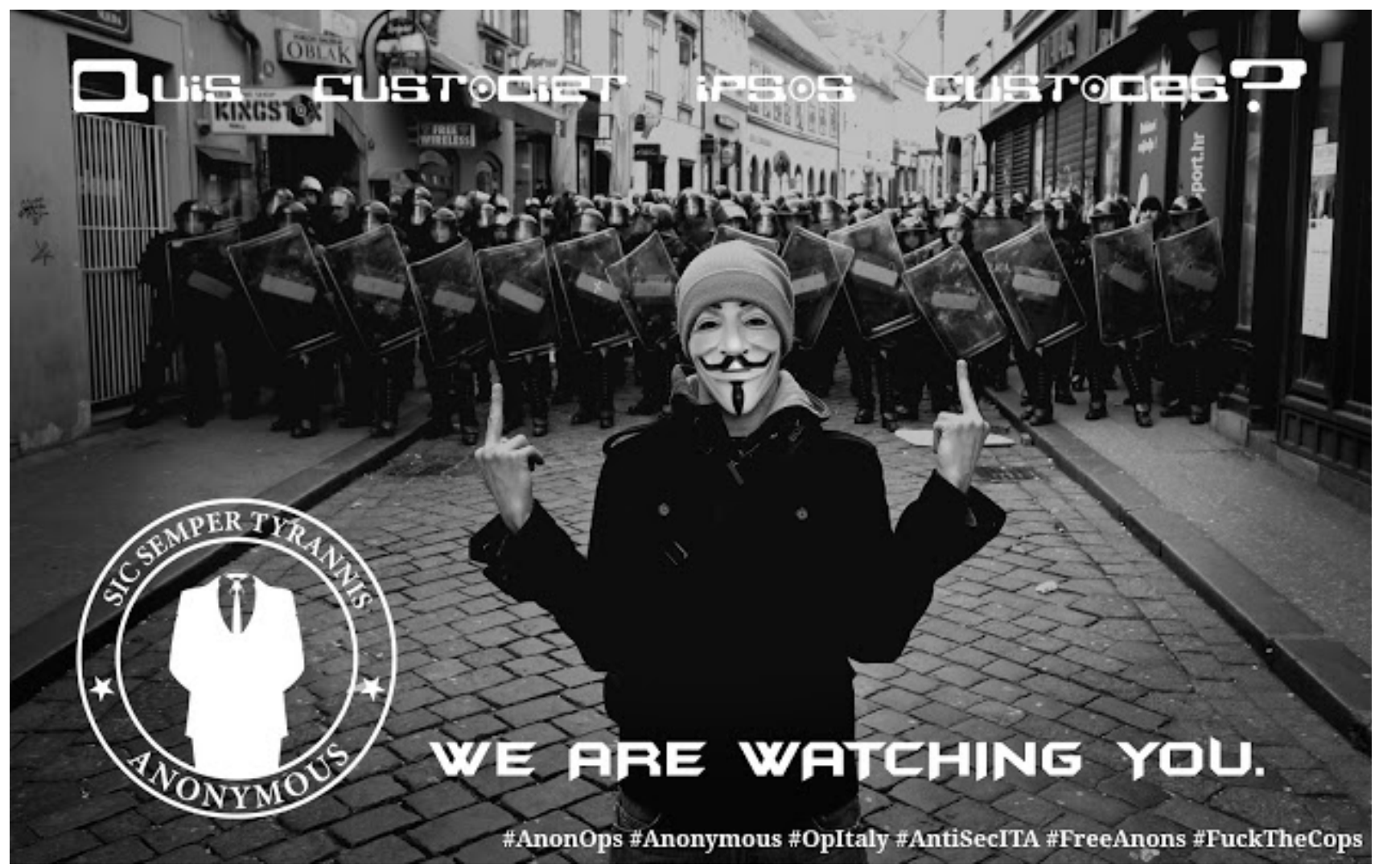

Figure 2. "Operation Police", part of Operation AntiSec. Flyer created and circulated by Anonymous to present the publication of a leak comprising documents of Italian police (Anonymous, 2012).

ticularly the timeless extraction and archiving of massive amounts of data. ${ }^{18}$ Here, the allusion to the scenario of the bomb comprises the perception of the explosion. This surrounds us, and the death and destruction of the nuclear explosion are replaced by a neverending bombardment of information. The leak of digital cultures produces a gigantic outcome that, because of the ever-growing amount of data storage, is virtually proportional to the same capability that digital archiving will reach in a future that has yet to come. This is the deathly paradox of digital cultures: perpetually increasing the production of data by selecting and extracting life forms provokes their continual depletion, and increases the affective, quantitative "quality" of leaks. ${ }^{19}$ This paradox is the symptom of an inherent potentiality; one that overcomes the "informative" content of the leak and displays its ability to affect beyond the narratives that rough documents would ever reveal, being as well the indicator of the emergence of a novel relation between the political sphere and media agential capacities.

Following this line of argument, I propose that the politics of leaks are not simply concerned with representation, but also with material, affective elements. Instead of simply working through the narratives of the disclosed documents that are published, leaks entail a political register that operates in the affective field. When data leaks are approached through the paradigm of representation-concentrating on the secret meanings they might convey-their political capacity to activate certain potentials beyond these narratives is stubbornly dismissed. Representation implies, in fact, an unbridgeable separation that relies on rationality and its superior capacity to comprehend the intelligible via the origination of middle points-as precisely what representations are. In the tradition of communication and cultural studies the conceptualisation of media derives from the identification of societal formations-often posed in oppositional terms - in which "mediation" negotiates among these pre-existing structures (Couldry, 2008; Lister, Dovey, Giddings, Grant, \& Kelly, 2009). In such a view, media are pre-supposed as static, "middle" tools, and scholarly analyses predominantly focus on the effects of the transmitted communications on different social groups.

Within this paradigm, leaks end up being considered as operating on a mere symbolic plane. In the never neutral outputs of representational analyses, leaks become conspiracies: they will unveil hidden secrets, functioning

\footnotetext{
18 James Graham Ballard's The Atrocity Exhibition (2001/1970) is a speculative theory that anticipates the distributed hypertrophy of contemporary digital media consumption.

19 Implicit here is an ecological perspective of media that acknowledges the key vital and material qualities of technological mediation (for details, see Fuller, 2005; Guattari, 2000).
} 
in the fiction of a disjunction that creates foes as an opposition of antinomic poles. ${ }^{20} \mathrm{Here}$, the "meaning" of every single leak will always take into consideration possible plot scenarios-grey areas in which power is portrayed as a matter of secret summits, invisible intrigues, and top brasses. Such representationalism reflects an illuminating transcendence; an inconvenient truth that only leaks allow to be revealed. As such, leaks symbolically operate through a fascistic logic-that is, by establishing binary oppositions: antinomies that originate enemies as alterities..$^{21}$ This is a logic that separates from the continuum, rather than looking at the way power relations can ontologically create both subjects and objects, friends and foes-ultimately downplaying via signification the vital, material, and entangled dimensions of semiotic processes.

Fuller and Goffey (2012) outline a sort of taxonomy of leaks: "Leak early, leak often" is one of the stratagems they ascribe to the "evil" of computational culture and its processes of "grey" mediation (p. 100). Literary criticism has, for many years, contributed to the study and classification of narrative models: this is how stories are told, passing from one generation to another throughout history. The conventional tradition of media and cultural research centres the analytical interest on the meanings and the structures of the narrations that are transmitted. However, to the contrary, according to Fuller and Goffey (2012), the same academic attention has not been dedicated to "the means by which stories become known" (pp. 100-101). Leaks are amongst these means, but they have never been the object of academic interest, even though being a "crucial means for the dissemination of every kind of narrative" (p. 101).

The issue, for Fuller and Goffey (2012), concerns the "kinds of ways" in which leaks emerge and then become available: the middles, the transformative processes or mediations of how this happens (p. 100). "The leak is the emission liberated from its proper place by an act of omission, or neglect of right containment" (Fuller \& Goffey, 2012, p. 101). The forms recognised by Fuller and Goffey are numerous: the draft, which outlines its own future disclosure; the offer of an exclusive; the accident, which is "the most propitious form of leak"; the elimination, a trash that is incapable of deleting its own content; as well as the whistle-blower, who aims to reveal an injustice suffered (pp. 101-103). In their account, rather than being an exhaustive classification, this is outlined as a moving set-a "rough diagram" of leaking (p. 101). For this reason, I experimentally take the advantage of this roughness to add to their scattered arrangement also the leaks that originate by forcing containment. These are forms of leaks that arise from hacking media practices such as those undertaken in the action introduced in the previous section.

Activation, by cracking, is another way of stimulating the emergence of leaks: a "kind of way" that takes advantage of the virtuality of system vulnerabilities. ${ }^{22}$ It is at this point that chinks open, and leaks appear. After all, codes have always been compiled in order to "securitise" a system, precisely because systems already contain their own exploits. The leak is a consequence, an accident that is already part of the archiving process, of the system fostering such a loss of content: the leak is always already virtually present. This reading of cracking as a matter of processual activation enable a possible politico-vitalist understanding of the set of hacktions at stake here, and in particular of Anonymous's deployment of such media weapons. This vital dimension is central to move the argument towards an affective register.

According to the diagrammatic classification of "evil media", a leak can take different forms, but, as already introduced, its key character is its virtuality:

The leak can be understood as a speech act with an unwilling speaker, but it can also remain simply as a gray anticipation, a document waiting nowhere for the eyes of no one, held in abeyance by a forensic disinterest. Such a leak is like every other document, an anonymous squirt into the ocean, but one that dreams of becoming the centre of a whirlpool. The leak, then, is an attempt to capture and mobilize the dynamics of unintended consequences, to enter in the domain of the accident, the double agent, confusion, and to render it fruitful. (Fuller \& Goffey, 2012, p. 103)

Leaked data can provoke a storm, or rest forever on the seabed without ever being revealed. Nevertheless, it is in the latter eventuality that the politics of data leaks enter the battlefield; media practices such as cracking trigger the virtuality of certain possibilities, and point to the chance for a leak to become a storm. Within contemporary forms of leaking, media codes are part of the "war machinic" deployment of digital media and networks as weapons (Micali, 2016). This intrinsic condition of network ecologies led to the widespread deployments of

\footnotetext{
20 On the culture of conspiracy, see Michael Barkun's (2003) influential study which albeit focused only on the American context, reveals certain key connections between conspiracy and the mass distribution of the internet.

21 The adjective "fascistic" is used here as Guattari employs it in his own work, as well as his collective work with Deleuze. "Fascist" does not exclusively refer here to the historical case of Italian Fascism, but to the modalities of oppression and repression of otherness-for instance as happened (and still happens) in the historical cases of fascisms. Guattari uses both the adjective "fascistic" and "fascist" throughout his writings in order to express the functioning of fascism at the molecular level-that is at the level of the production of subjectivity (e.g., Deleuze \& Guattari, 1977, 1987; Guattari, 1995, 2006). The best grounding on how fascism is at stake in the work of Guattari (and Deleuze) is to be found in Michel Foucault's (1977) preface to the American translation of Deleuze and Guattari's Anti-Oedipus. Regarding the dualistic creation of foes that is at the basis of right wing politics, see Wu Ming (2013).

22 The distinction between hacking and cracking comes directly from hackers, and accompanies the development of the whole literature on the hacker culture. Indeed, very often this distinction is presented as a dualistic one. Rather, I do not suppose them as oppositional terms; according to my perspective, cracking is a processual becoming of the hack. A step in this direction can be found in Jordan (2008).
} 
such hacktions, a trend in which it is possible to witness the global phenomenon of mass leaking such as WikiLeaks, as well as minor media actions such as those of the AntiSec campaign.

Rather than being simply a tool with which to transmit secret information, leaks act beyond the representation of their content and the narratives they communicate and disseminate: they may activate storms that are affective. In socio-political terms, they do not simply mediate between opaque and authoritarian societal structures in order to render them more transparent and, in accordance with a common rhetoric, more "democratic". Their politics does not directly depend on the actual content of their revelations. For these reasons, I suggest the politics of data leaks has to be considered instead through, and studied in, an affective register.

\section{Towards an Affective Politics of Data Leaks}

The concept of affect has gained relevance and interest within the field of the Humanities over recent decades. Since the concept has found various applications and approaches within different academic fields, its definition is neither "stable," nor is its understanding, which often overlaps with related-yet different-notions such as feeling or emotion. Therefore, there exists the need to posit a specific way of dealing with this concept.

As clearly emerges from the overview of the processes of mediation that are at stake in data leaks, they entail a key relationship with the virtual: they oscillate in-between an actual that is full of potential and the actualisation of this same potential-the possibilities that might arise by its emergence as a leak. As such, the notion of affect that equates it to intensity is the most productive with which to address the problem of leaking beyond the impasses of representationalism. To begin with, according to Félix Guattari:

Affect is...a pre-personal category, installed "before" the circumscription of identities, and manifested by unlocatable transferences, unlocatable with regard to their origin as well as with regard to their destination....As the color of the human soul as well as the color of animal becomings and of cosmic magics, affect remains hazy, atmospheric, and nevertheless perfectly apprehensible to the extent that it is characterized by the existence of threshold effects and reversals in polarity. (Guattari, 1990, pp. 66-67)

In his understanding of the affective register, Guattari was inspired by the work of Baruch Spinoza (1667/2013), and Deleuze's influential studies on the Dutch philosopher (Deleuze, 1992, 2001). The Spinozian suppositions on the "transitivist" character of affect are particularly significant. This character is the capacity of inten- sive interactions between bodies. As specified in the quote, these affective transferences cannot be localised in terms of origins and destinations, lying instead in "the midst of in-between-ness: in the capacities to act and be acted upon" (Gregg \& Seigworth, 2010, p. 1). Therefore, affect is traceable within the intensities that circulate and pass through bodies: within encounters between bodies. However, bodies here have a broader sense, one that surely cannot be circumscribed to the human body, and specifically not with its organicistic, static comprehension. These are the result of a material axis (longitude), and are in particular the result of the intensive merging of the affective forces in their actual constitution (the axis of latitude; see Baugh as cited in Parr, 2010; see also Deleuze, 2001; Deleuze \& Guattari, 1987). ${ }^{23}$

From the above quoted Guattarian description, it is also possible to underline the pre-personal dimension of affect, which regards the pre-rational and preconstitutional form of individuation. Key references for Guattari here are both the work of Gilbert Simondon (1989) on the ontogenesis of being, and the ethological studies of Daniel Stern (1998). The former regards the continual "meta-stability" of the individual in its becoming from a state of non-existence that does not conclude its pre-individual potential in the actuality of individuation (Simondon, 1989). The latter offers fundamental, direct observations and reflections on the preverbal subjective formation of the infant, showing her/his prerational activation through vitality affects (attunement) via the mother (Stern, 1985, 1998).

In his seminal text on the study of affect, Brian Massumi (2002) continues the line of thought that equates intensity with affect by recognising the essential different logics and orders that exist between affect and emotion. He identifies precisely the subjective character of emotion, pertaining to an order of intensity that is already qualified. Emotions, as well as feelings, already involve a rational recognition by the body/brain, and are open to structural-semiotic descriptions. Conversely, affect (as well as its definition) can barely be defined with words, since-put simply-its representation and rational explication constitute that which affect is not. Identifying emotion and/or feeling with affect runs, indeed, the serious risk of re-establishing the superiority of reason that shapes the drama of humanism and its related representationalism. Affect pertains to an a-signifying semiotic order, and must be apprehended as an order of intensive actualisation that exceeds by degree the perceptions of human-animals and their subjective states.

This outline of affect brings to the fore the crucial question of how intensity might be comprehended, particularly regarding the case of data leaks. A possible answer comes from the fact that, occupying the domain of the accident, the mediations of leaks operate in the dimension of the event. According to Deleuze (1990), the

\footnotetext{
${ }^{23}$ Deleuze's lectures on Spinoza are a key reading with which to gain an understanding of the question of the body from an anti-anthropocentric standpoint, casting equal light on the relationship between embodiment and affect. As far as I know, an English translation of the lectures has not been published, but they can be found on the web. In Italian they have been translated in Deleuze (2013).
} 
event is an immanent and particular set of relations that is provoked by the encounter and collision of various forces-virtually being the productive potential of those same forces (see also Lazzarato, 2004). As such, within the eventfulness of the social, affect is at stake through its intensive "potency"; it is, in fact, a category that operates before the actual individuation of subjective conditions, an intensity that signals the differential of change.

In such a register, leaks possess the affective capacity to trigger and activate subjects differentially, as a political propensity towards initialising and actuating latent tendencies that are already virtually present in the societal field. Data leaks thus present a kind of "affective politics" - one that Massumi (2015b) characterises as an "inductive" form of politics:

Politics, approached affectively, is an art of emitting the interruptive signs, triggering the cues, that attune bodies while activating their capacities differentially. Affective politics is inductive. Bodies can be induced into, or attuned to, certain regions of tendency, futurity, and potential...There are potential alter-politics at the collectively in-braced heart of every situation, even the most successfully conformist in its mode of attunement. You can return to that reservoir of real but unexpressed potential, and recue it. This would be a politics of microperception: a micropolitics. (Massumi, 2015b, pp. 108-109)

Affect is the power (or puissance) to intensively enable a transformation in the state of the forces at play; the possibility of generating novel relations within the emergent world that is constantly in a process of creation. In the case of the politics of data leaks, it has then to be investigated by casting light on some of the tendencies these might be capable of triggering. The affective politics of data leaks, playing within the vital domain of intensity, can-as such-be apprehended via a non-deterministic, intuitive approach.

To conclude this draft of the affective politics of data leaks, and point towards the future steps that need to be conducted in order to more sharply crystallise this emerging field of enquiry, I would like to draw out some final remarks on the key relationships between Anonymous's AntiSec releases of October 2012 and the NoTav movement. Indeed, as clearly emerges from the first section, the political resistances of this movement, and the guiding forces that populated it, were significantly involved in the actualisation of the leak, albeit without having been linearly determined or determined by it as such.

\section{Conclusion, or the Alter-Triggering of Anonymous Leaking}

The close discussion of the 2012 Anonymous data leak allowed me to glimpse the surfacing of an innovative set of relationships between the agential capacities of media and politics in digital cultures. The increasing quantities of information that can be stored in digital databases are, in fact, the potential of an overload: an informational surplus that-implying a dimension of action that exceeds the content of the revealed narratives-brings attention to the key question of the virtuality of leaks. (Big) data leaks have indeed a potentiality that tends towards the productivity of life itself-an endless cycle that paradoxically plays with the data capture and related depletion of living heterogeneity. As a result of the centrality of this virtual element, I argued that approaching and investigating data leaks as a matter of representation offers a limited understanding of this preeminent style of contemporary digital resistance. Attributing to the digital interventionism of data leaks a mere symbolic value sustains a sort of fascist logic that reads their particular mediations as a process capable of disclosing certain hidden plots: dark conspiracies that, creating a dualistic power ontology, assign to the leaked narrations a transcendental status of truth.

Conversely, to avoid the limits of this representationalist framework, I proposed the centrally of an affective order to non-deterministically apprehend the politics of data leaks; an order that entails the virtuality of leaking processes of mediation via their capacity to intensively activate certain latent tendencies. This means that, rather than merely being a tool to disclose secrets, data leaks operate within an affective register, implying a politics that acts in the eventful co-constitution of the societal field in its diverse gradations.

Given the programmatic objective of this article, I want to conclude with some final remarks on the relationships between the leak of Anonymous and the NoTav movement, highlighting some points that-once fully developed-can lead to further research on the affective politics of data leaks. These concluding remarks treat the ongoing nature of the phenomena that have been taken into consideration; their capacity to activate collective responses; the key indication they might offer in the study of contemporary power apparatuses; and a similar indication concerning resistance to these forms of power-affective alter-politics that can intensively coparticipate in the constitution of collective, resistant subjective formations.

Significantly, the AntiSec campaign is not over: it is still ongoing, and day-by-day involves novel hacktions and targets. This means that the processes that I discuss here are still in motion, even after the repression and arrests that have occurred since 2012. As I write, Anonymous Italia is currently releasing data obtained from the Italian Ministry of Defence and the Ministry of Internal Affairs (Ministero della Difesa and Ministero degli Interni), the Italian government, and the Navy (Marina Militare Italiana)-data that comprise a list of institutional email addresses and scanned copies of the identity cards and passports of functionaries working within state bureaucracies (for details, see Securityinfo, 2017).

Returning now to 2012, on the $23^{\text {rd }}$ of October one of the principal webpages of the NoTav move- 
ment (http://www.notav.info) published a post thanking Anonymous for the leak of the previous day. The hacktion was not the first, nor was it to be the last deployed by Anonymous to enter the battlefield in support of the grassroots movement. However, for the first time the movement faced a vast amount of information that was originally produced by the police to directly stop, limit, and criminalise its activities. Together with its gratitude for the diffusion of the documents, the post reports the will of the activists to scrutinise and analyse the data. The point is not then to overlook the informative value these data might have-especially for the movement and its participants-but to recognise the leaking hacktion of Anonymous as a cue that had the potential to activate collective responses: an affective alter-politics, or micropolitics, that can co-determine the emergence of collective and individual subjective formations, flowing towards shared regions of tendency. ${ }^{24}$

The leaked data-before being released-formed part of a repressive machine in which they were extracted, produced, and stored to generate homogeneous spaces that would not manifest any contradiction. Considering the field of affective politics as introduced, many of these data did not have a direct, immediate informative value. Rather they supported a logic of "preemption" (Elmer \& Opel, 2006, 2008): a "technology" of control that collects information on the present in order to anticipate the risks of an inevitable future, thus directing the former towards certain regions of secured futurity. ${ }^{25}$ Indeed, the choice of the Italian government in 2011 to declare a national strategic interest in part of the construction area, as well as the deployment of the accusation of terrorism against some activists of the movement in 2013, precisely support this preemptive logic. This power strategy works via affective diagrams, preemptively mobilising the responses to any possible form of dissent. These dispositifs implicate data as processes of mediation that, within larger controlling machines, are able to anticipate and address - in this case local-forms of dissent towards secure scenarios.

However, the data leaks of Anonymous worked differently. Virtually escaping such machines of control, they became alter-cues of affective politics; triggers by which to instigate alternative modes of attuning towards a common future. These data leaks have prompted resistant forces that were already dynamically active in the territory, instigating their potential extent. On the $28^{\text {th }}$ of October 2012, more than thousand NoTav activists from all over the country participated in the collective purchase of the terrains on which one of the high-speed train stations had to be built. A couple of days later, on the $3^{\text {rd }}$ of November, the movement re-occupied an area that was under a sequester order of the police because of its proximity to the construction site. The resistant politics of data leaking has surely taken part in the activation of certain novel events within a short interval of time. Nevertheless, more importantly, it contributed to maintain a certain lasting set of relationships, diverting attempts to dissipate their active forces of dissent, instead reinforcing the ranks of the movement and accompanying it towards today's common struggles and those that have yet to come.

In conclusion, the case of the data leak of Anonymous and, especially, its vital entanglements with the NoTav movement, shows the emergence of an innovative style of media dissent that is pre-eminently surfacing in contemporary network cultures. In particular, this emerging form of media interventionism can be addressed and understood as a key configuration of affective politics or, better, as alter-politics. This configuration has, in fact, the capacity to act by exceeding the content of the documents that are released, intensively co-participating in the individuation of certain latent tendencies. This means that the politics of data leaks operates in the domain of affect-a register that, as outlined in this programmatic proposal, pertains to the virtual and potential capacities of triggering and inducting certain active forces of resistance.

\section{Conflict of Interests}

The author declares no conflict of interests.

\section{References}

Aime, M. (2016). Fuori dal tunnel: Viaggio antropologico nella Val di Susa [Outside of the tunnel: Anthropological travel across Val di Susa]. Milan: Meltemi.

Anonymous. (2011, June 19). Operation anti-security. Pastebin. Retrieved from http://pastebin.com/ 9KYAOE5V

Anonymous. (2012, October 22). \#AntiSecITA-Polizia Italiana Owned \& Exposed. Anon News.

Arizona Department of Public Safety. (2011, June 27). DPS victim of cyber attack. Arizona Department of Public Safety. Retrieved from https://www.azdps.gov

Ballard, J. G. (2001). The atrocity exhibition. London: Harper Collins Publishers. (Original work published 1970)

Barkun, M. (2003). A culture of conspiracy: Apocalyptic visions in contemporary America. Berkley, CA: University of California Press.

Bazzichelli, T. (2013). Networked disruption: Rethinking oppositions in art, hacktivism and the business of social networking. Aarhus: Digital Aesthetics Research Center.

Berardi, F. (2004). Il sapiente, il mercante, il guerriero: Dal rifiuto del lavoro all'emergere del cognitariato

\footnotetext{
24 The concept of micropolitics traverses the work of Deleuze and Guattari and can be briefly described as the flowing politics of the production of subjectivity. In particular, see Deleuze and Guattari $(1987,9)$.

25 Here, I employ the term "technology" beyond its strict definition as a material artefact, regarding it as a plausible translation of the French word "dispositif" (often translated in English as apparatus), which is a key concept for post-structuralist accounts of power; for instance, see Foucault (1995).
} 
[The sage, the merchant, the warrior; From the refusal of work to the emergence of cognitariat]. Rome: Derive Approdi.

Burroughs, W. S. (1961). The soft machine. Paris: Olympia Press.

Burroughs, W. S. (1962). The ticket that exploded. Paris: Olympia Press.

Burroughs, W. S. (1964). Nova express. New York, NY: Grove Press.

Burroughs, W. S. (1971). The wild boys. New York: Grove Press.

Centro Sociale Askatasuna. (2012). A sarà düra: Storie di vita e militanza no tav [A sarà düra; Tales of notav life and militancy]. Rome: Derive Approdi.

Chapman, S. (2011, June 20). Operation Anti-Security: LulzSec and Anonymous target banks and governments. ZDNet. Retrieved from https://www. zdnet.com/article/operation-anti-security-lulzsec-and -anonymous-target-banks-and-governments

Coleman, G. (2014). Hacker, hoaxer, whistleblower, spy: The many faces of Anonymous. London: Verso.

Constantin, L. (2011, September 2). Anonymous hits Texas law enforcement. The Inquirer. Retrieved from https://www.theinquirer.net/inquirer/news/210626 7/anonymous-hits-texas-law-enforcement

Couldry, N. (2008). Mediatization or mediation? Alternative understandings of the emergent space of digital storytelling. New Media \& Society, 10(3), 373-391.

Deleuze, G. (1990). The logic of sense. New York, NY: Columbia University Press.

Deleuze, G. (1992). Expressionism in philosophy: Spinoza. New York, NY: Zone Book.

Deleuze, G. (2001). Spinoza: Practical philosophy. San Francisco, CA: City Light Books.

Deleuze, G. (2013). Cosa può un corpo? Lezioni su Spinoza [What can a body do? Lessons on Spinoza]. Verona: Ombre Corte.

Deleuze, G., \& Guattari, F. (1977). Anti-Oedipus: Capitalism and schizophrenia. New York, NY: Viking Press.

Deleuze, G., \& Guattari, F. (1987). A thousand plateaus: Capitalism and schizophrenia. Minneapolis, MN: University of Minnesota Press.

Elmer, G., \& Opel, A. (2006). Surviving the inevitable future. Cultural Studies, 20(4/5), 477-492.

Elmer, G., \& Opel, A. (2008). Preempting dissent: The politics of an inevitable future. Winnipeg: Arbeiter Ring Publishing.

Foucault, M. (1977). Preface. In G. Deleuze \& F. Guattari, Anti-Oedipus: Capitalism and schizophrenia (pp. xixiv). New York, NY: Viking Press.

Foucault, M. (1995). Discipline and punish: The birth of the prison. New York, NY: Vintage Books.

Fuller, M. (2005). Media ecologies: Materialist energies in art and technoculture. Cambridge, MA: MIT Press.

Fuller, M., \& Goffey, A. (2012). Evil media. Cambridge, $\mathrm{MA}$, and London: MIT Press.

Gregg, M., \& Seigworth, G. J. (2010). The affect theory reader. Durham, NC: Duke University Press.
Guareschi, M. (2001). Deleuze popfilosofo [Deleuze popphilosopher]. Milan: Shake.

Guattari, F. (1990). Ritornellos and existential affects. Discourse, 12(2), 66-81.

Guattari, F. (1995). Chaosmosis: An ethico-aesthetic paradigm. Indianapolis, IN: Indiana University Press.

Guattari, F. (2000). The three ecologies. London: The Athlone Press.

Guattari, F. (2006). The anti-Oedipus papers. New York, NY: Semiotext(e).

II Fatto Quotidiano. (2012, October 23). Anonymous viola il sito della Polizia, 3500 documenti finiscono in Rete [Anonymous breaks the Police website, 3500 documents released online]. II Fatto Quotidiano. Retrieved from https://www.ilfattoquotidiano.it/ 2012/10/23/anonymous-viola-sito-della-polizia-3500 -documenti-finiscono-in-rete/390527

InfoFreeFlow. (2012, October 23). AntiSeclta affonda poliziadistato.it [AntiSeclta sinks poliziadistato.it]. InfoFreeFlow. Retrieved from https://infofreeflow. noblogs.org/post/2012/10/23/antisecita-affonda-po liziadistato-it

Ippolita. (2012). Nell'acquario di Facebook [In the Facebook Aquarium]. Milan: Ledizioni.

Jordan, T. (2008). Hacking. Cambridge: Polity Press

Kember, S., \& Zylinska, J. (2012). Life after new media: Mediation as a vital process. London: MIT Press.

Lazzarato, M. (2004). La politica dell'evento [The politics of the event]. Soveria Mannelli: Rubbettino Editore.

Lister, M., Dovey, J., Giddings, S., Grant, I., \& Kelly, K. (2009). New media: A critical introduction (2nd ed.). London: Routledge.

Massumi, B. (2002). Parables for the virtual: Movement, affect, sensation. Durham, NC: Duke University Press.

Massumi, B. (2010). The future birth of the affective fact: The political ontology of threat. In M. Gregg \& G. J. Seigworth (Eds.), The affect theory reader (pp. 52-70). Durham, NC: Duke University Press.

Massumi, B. (2015a). Politics of affect. Cambridge: Polity Press.

Massumi, B. (2015b). The power at the end of the economy. Durham, NC: Duke University Press.

Micali, A. (2016). Hacktivism and the heterogeneity of resistance in digital cultures (Unpublished doctoral dissertation). University of Lincoln, Lincoln, UK.

Micali, A. (2017a). Media actions as hacktions: Rethinking resistance(s) in network ecologies. Critical Studies, 3(1), 3-19.

Micali, A. (2017b). Towards a nonlinear, material history of digital swarms. Internet Histories: Digital Technology, Culture and Society, 1(3), 238-257.

NoTav.info. (2012, October 23). Grazie Anonymous! NoTav.info. Retrieved from www.notav.info/post/grazieanonymous

Olson, P. (2012). We are Anonymous. New York, NY: Hachette Book Group.

Parr, A. (Ed.). (2010). The Deleuze dictionary: Revised edition. Edinburgh: Edinburgh University Press. 
Securityinfo. (2017, November 14). Torna Anonymous Italia: "Abbiamo i dati del governo" [Anonymous Italia is back: "We have the data of the government"]. Securityinfo. Retrieved from https://www.security info.it/2017/11/14/torna-anonymous-italia-dati-delgoverno

Serracino-Inglott, P. (2013). Is it OK to be an Anonymous? Ethics \& Global Politics, 6(4), 217-244. doi:10.3402/egp.v6i4.22527

Simondon, G. (1989). L'individuation psychique et collective [Psychic and collective individuation]. Paris: Editions Aubier.

Spinoza, B. (2013). Etica e trattato teologico-politico [Ethics and theological-political treatise]. Novara: De Agostini. (Original work published 1667)

Stern, D. N. (1985). Affect attunement. In J. D. Call, F.
Galenson, \& R. L. Tyson (Eds.), Frontiers of infant psychiatry (Vol. 2) (pp. 3-14). New York, NY: Basic Books. Stern, D. N. (1998). The interpersonal world of the infant: $A$ view from psychoanalysis and developmental psychology. London: Karnac Books.

Thomas, D. (2002). Hacker culture. Minneapolis, MN: University of Minnesota Press.

Virilio, P. (2000). The information bomb. London: Verso.

Wu Ming. (2013, February 20). Consigli per riconoscere la destra sotto qualunque maschera [Advices to recognise the right wing under any mask]. Giap. Retrieved from www.wumingfoundation.com/giap/?p=11977

Wu Ming 1. (2016). Un viaggio che non promettiamo breve: Venticinque anni di lotte No Tav [A travel that we do not promise will be short: Twenty-five years of No Tav struggles]. Turin: Einaudi.

\section{About the Author}

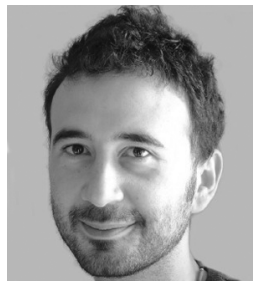

Alberto Micali, PhD, is Lecturer in Communications and Media Studies in the Communications Faculty at the John Cabot University, Italy; and Associate Lecturer in the School of Film and Media at the University of Lincoln, UK. His research interests lie in the politics of digital media and network dissent, focussing on the social and political implications of hacking, digital activism, and non-representational theories of media and mediation. His work appeared in journals such as Internet Histories: Digital Technology, Culture and Society; Critical Studies; and the Journal of Posthuman Studies. 